\title{
On the Possible Death of Monsieur Smith Patrick Lawler
}

He's been trying to tell me he's died. The evidence Came in for years, but I ignored it. He lined His office walls with burial jars from Egypt.

I examine his memos for clues of his demise:

Requiems for a clavichord he composed in secret, Passages from a Tibetan book he copied during Lunch. His habits confirm this: his desk faces The west; a tile removed from the roof is kept In a locked drawer. I explore the odds And the ends, his jump to conclusion, the dum-de-dum Of ledgers written in red ochre. I speak

To his possible widow about his possible demise. It Lets him do the things he does so well unnoticed. 